Vol. 11 (1): 89-96 (2021)

\title{
COMPARISON OF WINTER BARLEY VARIETIES (HORDEUM VULGARE) FOR BEER IN CLIMATIC ZONES IN KOSOVO
}

\author{
Nexhdet Shala ${ }^{1}$, Arsim Elshani ${ }^{1 *}$, Ibrahim Hoxha ${ }^{1}$, Indrit Loshi ${ }^{1}$, Besiana Hoxha ${ }^{1}$ \\ I*University “Haxhi Zeka”, Str. UÇK 30000 Peja, Republic of Kosovo, 30000 Peja, Kosovo; \\ *Corresponding Author Arsim Elshani, e-mail:arsim.elshani@unhz.eu;
}

Received November 2020; Accepted December 2020; Published January 2021;

DOI: https://doi.org/10.31407/ijees11.112

\begin{abstract}
The purpose of this study is the analysis of breeding/cultivation and production of autumn barley for beer (Hordeum vulgare) in the climatic conditions of the Republic of Kosovo. In the cultivation analysis and production have been included a total of five barley cultivars: Bingo, Zlatko, Vannesa, Esterel and Rex as comparative (standard). Analysis of breeding and production are conducted in two regions: Dukagjini Plain, and Kosovo Plain. The experiments have been settled by the method of randomized blocks in their repetitions. Area of each experimental plot was $10 \mathrm{~m}^{2}$. In analyzing the cultivation and production, have been analyzed yield $(\mathrm{kg} / \mathrm{ha})$, weight (1000 seeds in grams) hectoliters weight $(\mathrm{kg})$, protein content $(\%)$ humidity $(\%)$, and starch. Results obtained showed that there were significant statistical differences at different levels for all traits investigated cultivars involved in plots and compared with the standard (Rex) and also between regions.
\end{abstract}

Keywords: barley varieties, seed weight, hectoliters weight, yield. 